\title{
THE EFFECTS OF INCENTIVES AND LEADERSHIP STYLES ON AGENT WORK PERFORMANCE IN PT ASURANSI TAKAFUL KELUARGA REPRESENTATIVE OFFICE RIAU AGENCY PEKANBARU
}

\author{
Zulkifli \\ Fakultas Agama Islam, Universitas Islam Riau \\ Email: zulkifli_rusby@fis.uir.ac.id
}

\begin{abstract}
ABSTRAK
PT. Asuransi Takaful Keluarga RO Riau Agency Pekanbaru sangat memperhatikan SDM di perusahaannya. Rumusan masalah penelitian ini adalah bagaimana pengaruh insentif dan gaya kepemimpinan terhadap prestasi kerja agen. Jenis data yang digunakan dalam penelitian ini adalah data primer dan data sekunder. Teknik pengambilan sampel digunakan dengan cara sampel jenuh, sedangkan teknik pengumpulan data dilakukan dengan penyebaran angket. Untuk menganalisis data digunakan metode deskriptif kuantitatif. Dalam menganalisis data kuantitatif digunakan analisis linier berganda menggunakan SPSS for Windows version 23.0. hasil penelitian ini diketahui hubungan insentif dan gaya kepemimpinan terhadap prestasi kerja agen memiliki hubungan yang cukup kuat sebesar 0.546, Sedangkan hasil uji parsial terdapat pengaruh yang signifikan antara insentif terhadap prestasi kerja agen, ini diketahui dari tingkat signifikan sebesar 1,809 dan terdapat pengaruh yang signifikan antara gaya kepemimpinan terhadap prestasi kerja agen, ini diketahui dari tingkat signifikan sebesar 2,185. Secara umum dapat disimpulkan bahwa insentif dan gaya kepemimpinan terhadap prestasi kerja agen pada PT. Asuransi Takaful Representive Office Riau Agency Pekanbaru berpengaruh.
\end{abstract}

Kata Kunci : Insentif, Gaya Kepemimpinan, Prestasi Kerja, Takaful.

\begin{abstract}
PT Asuransi Takaful Keluarga RO Riau Agency Pekanbaru that observes the Human Resource in their company. The research problem is how incentives and leadership style impact to agent work performance. The data used in this study were primary data and secondary data. The sampling technique used was saturation sampling, while the data collection technique used was questionnaire distribution. Quantitative descriptive method was used to analyse the data. In analysis quantitative data, multiple linear analyses were used using SPSS for Windows version 23.0. The results showed that there is a strong correlation between incentives and leadership styles with a score of 0.546. As for the results of partial test, there is a significance effect of incentives on agent work performance, which is indicated by a significance level of 1.809 and there is a significance effect of leadership styles on agent work performance, which is indicated by a significance level of 2.185. Principally, it can be concluded that incentives and leadership styles impact to agent work performance in PT Asuransi Takaful Keluarga RO Riau Agency Pekanbaru.
\end{abstract}

Keywords: Incentives, Leadership Styles, Work Performance, Takaful. 


\section{INTRODUCTION}

Human resources are the only resource blessed with senses, feelings, desires, skills, knowledge, drives, power, and works (mind, heart, and soul). Each one of those human resource potentials affects the organization's efforts to achieve goals. It would be an uphill battle for an organization to achieve goals without human resources, despite technological advancement, information development, capital and material availability.

Human resource management is part of management as a whole. Therefore, human resource management focuses its discipline on the regulations of human roles in actualizing optimal targets. The regulations encompass the issue of planning, organization, directing, control, procurement, development, compensation, integration, maintenance, discipline and termination of employment to support the realisation of company goals, employee and society satisfaction (Hasibuan, 2009). Incentive policy is an important aspect to note since this aspect is correlated with the work of employees in carrying out tasks and performing their duties. By giving incentives in accordance with the work standard set, it gives satisfaction and fosters strong relationship between employees and the organization where they work. Therefore, relationship that leads to the achievement of objectives will greatly benefit the organization, such as PT Asuransi Takaful Keluarga Representative Office (RO) Riau Agency Pekanbaru. An agent is a person or a legal entity that provides service in marketing insurance services for and on behalf of insurance companies (Soemitra, 2009). In conducting the preresearch, the author interviewed a number of agents in PT. Asuransi Takaful Keluarga Representative Office
RO Riau Agency Pekanbaru, from which the author found that agents are hard at work in procuring clients in order to gain incentives.

\section{LITERATURE REVIEW}

\section{Incentive}

Incentives are a stimulation or encouragement for employees in an organization to stimulate greater productivity. By giving incentives, employees will feel more valued and respected for the services they provide (Winardi, 2008). Incentives are the source of performance feedbacks for a group of high achiever employees, especially when it is given as a bonus and appreciated by people that desire greater success as a driver to perform better in work (Handoko, 2013). Incentives connect the appreciation and performance by giving performance bonus that is not based on seniority and working hour. While incentives are given to groups, they often appreciate individual behaviors. Incentive program is devised as such to boost employee motivation.

The objective of incentives in an organization, especially in production activity, is to boost employee work productivity by encouraging employees to work harder, faster, more diligently and creatively. While for employees, incentives bring advantages as a performance standard measured quantitatively and as the basis of remuneration in form of money.

\section{Leadership}

Effective leadership will only be realized if it is carried out in line with its functions. The leadership function directly correlates with the social situation in the lives of each group or organization, implying that every leader exists inside, not outside, of the situation. Leadership function is a social 
phenomenon, because it must be realized in interactions between individuals in a social situation of a group or an organization. Since leadership function greatly impacts the progress and decline of an organization, the division of work within an organization will not work well without clear definition of the function of the leader.

Sodang P. Siagian, in his book, Teori dan Praktek Kepemimpinan, said that some of the functions of a leader are as a director in their efforts to achieve goals, as a representative and a spokesperson in relation to parties outside the organization, as a mediator, especially in inward relationship, to diffuse conflicts and as an effective, rational, objective and neutral integrator (Siagian, 1999).

\section{Leadership Sytle}

William H. Newman (1968), in Thoha (2003), said that leadership is an act to influence other people's behaviors or an art of influencing human behaviors, both in individuals and groups. One thing to note is that leadership is not constrained by regulations and bureaucratic manners. Leadership can happen anywhere, so long as the person manifests the capability of influencing other people's behaviors toward the achievement of a certain goal. Leadership styles can be defined as the manifestation of a behavior of a leader related to his/her capability to lead. This manifestation usually forms a certain pattern or shape. This definition of leadership style is consistent with the argument expressed by Davis K and Newstrom (1995). Both said that a pattern of leader action as a whole as perceived or referenced by subordinates is known as leadership style (Tjiptono, 2006). Leadership style is a method used by a leader to interact with their subordinates. The forms of leadership style are as follows:

- Autocratic Leadership

- Democratic Leadership

- Delegative Leadership

- Bureaucratic Leadership

- Laissez-Faire Leadership

- Charismatic Leadership

- Diplomatic Leadership

- Moralist Leadership

- Administrative Leadership

- Analytical Leadership

- Assertive Leadership

- Entrepreneurial Leadership

- Visionary Leadership

- Situational Leadership

- Traits Model of Leadership

- Military Leadership

\section{Work Performance}

According to Sutrisno (2009), work performance is a work outcome achieved by one through their behavior in doing work activities and information related to the high and the low of work performance of an employee. According to Hasibuan (2013), work performance is a work outcome achieved by one in doing the tasks given based on the skills, experience, and dedication and time (timeliness). Work performance is a combination of three important factors, namely skills and interests of an employee, skills and acceptance of task delegation, and roles and motivation level of an employee. The higher the three factors above are, the greater the work performance of an employee will be. 


\section{Factors Influencing Work Performance}

According to Sutrisno (2009), there are two factors influencing work performance, which are individual and environmental factors. Individual factor measures the behavior itself or to what extent the individual behave in accordance with what is expected by the organization or institution, in other words, work performance that is generally linked to achievement of results from established work standards. In this study is work performance measurement.

\section{Takaful Insurance}

Insurance is an agreement where the insuring party commits to to the insured party by obtaining premium to compensate for a loss, or un-obtained expected profit, which may be due to an unexpected event.

Insurance, in an economic perspective, is a method to reduce risk by moving and combining uncertainty about financial losses. In a business perspective, insurance is a business whose main enterprise is to accept/sell service, risk transfer from other parties and obtain benefits with various risks among a number of customers. From a social perspective, insurance is a social organization that accepts risk transfer and collects funds from members to compensate losses that may happen to each of its members (Soemitra, 2009).

According to Article 246 of the Commercial Law Code (KUHD) of The Republic of Indonesia, insurance is an agreement, in which the insuring party commits to the insured party by accepting premium, to pay compensation for a loss due to a loss, damage or unobtained profit, which may be suffered due to an uncertain event (Ali, 2008).
In Arabic, insurance is called Atta'min, the insuring party is called mu'aimin, and the insured party is called mua'mmanlahu or musta'min AtTa'min, which are taken from the word amanah that means providing protection, serenity, security and freedom of fear (Syakir Sula, 2004).

Takaful, in muamalah sense, is bearing risk among people so that between one another the insurer insures for the others' risks. This mutual insurance is carried out on the basis of mutual help in kindness by expending tabarru' fund, a donation intended for bearing risks. Takaful, in this sense, is in accordance with Quran verses in surah Al-Maidah [5:2]. This principle of insurance, according to it, is very good and commendable, because it relieves other people's burden hit by a problem. According to Fatwa No. 21/DSNMUI/X/2001 on General Guidelines for Sharia Insurance, insurance is an effort to protect and help between people/parties through investment in the form of tabarru' asset that offer trading pattern to bear certain risk through akad (agreement) in accordance with sharia law (Ali, 2008).

\section{RESEARCH METODH \\ Research Designs}

The design of this study is causality study, which is a study to analyze the possibility of causalities between variables. In this design, causalities generally can already be predicted by researchers and the researchers are able to determine the classification of independent variables and dependent variables (Sanusi, 2014).

\section{Instrument Test}

Research instruments are measuring instruments or tools. Valid instruments mean that the measuring instruments used are valid (Sanusi, 
2014). Instrument test used in this study is validity and reliability tests. Multiple regressions were used to predict the dependent variables (Y) if the independent variables $(\mathrm{X})$ are known. The equation of the multiple regressions is as follows (Hasan, 2008).

Where:$$
\text { Y }
$$$$
=\text { dependent }
$$
(predicted value Y)

variables

$\mathrm{X} 1 \mathrm{X} 2=$ independent variables with certain value to predict

$\mathrm{a}, \mathrm{b} 2, \mathrm{~b} 2=$ multiple linear regression coefficient

a $\quad=$ Y value, if $\mathrm{X} 1=\mathrm{X} 2=0$

b1 $=$ the amount of increase/decrease in $\mathrm{Y}$ in units, if $\mathrm{X} 1$ increases/decreases one unit and X2 is constant

b2 = the amount of increase/decrease in $\mathrm{Y}$ in units, if $\mathrm{X} 2$ increases/decreases one unit and $\mathrm{X} 1$ is constant

+ or $-\quad=$ symbol that indicates the direction of the relation between $\mathrm{Y}$ and $\mathrm{X} 1$ and $\mathrm{X} 2$.
Multiple determinant coefficient, symbolized by KPBY.12 or R2, is used to measure how significant the contribution of dependent variables (X) together to dependent variables (Y). According to Akdon and Riduwan (2013), the method to identify the determinant coefficient to square correlation coefficient value with the following formula:

Where:

$$
\begin{array}{ll}
\mathrm{KP} & =\text { Determinant coefficient } \\
\mathrm{r} & =\text { Correlation coefficient value }
\end{array}
$$

\section{Hypothesis Test}

$\mathrm{T}$ Test is conducted to identify the influence of each independent variable on dependent variables. The step is to formulate the hypothesis and determine the level of significance of $\alpha=$ 0.05 . while $F$ test is used to identify the influence of independent variables (X) together on dependent variables (Y).

\section{RESULT AND FINDING}

\begin{tabular}{|c|c|c|c|}
\hline Variables & Statement Items & $\begin{array}{l}\text { Corrected Item-Total } \\
\text { Correlation (R Count) }\end{array}$ & $\begin{array}{l}\text { Result Description } \\
\text { (If } r \text { count }>0.3 \text { “valid") }\end{array}$ \\
\hline \multirow{10}{*}{$\mathrm{X} 1$} & Item 1 & 0,821 & Valid \\
\hline & Item 2 & 0,803 & Valid \\
\hline & Item 3 & 0,892 & Valid \\
\hline & Item 4 & 0,880 & Valid \\
\hline & Item 5 & 0,664 & Valid \\
\hline & Item 6 & 0,658 & Valid \\
\hline & Item 7 & 0,778 & Valid \\
\hline & Item 8 & 0,545 & Valid \\
\hline & Item 9 & 0,694 & Valid \\
\hline & Item 10 & 0,699 & Valid \\
\hline \multirow[t]{7}{*}{$\mathrm{X} 2$} & Item 11 & 0,395 & Invalid \\
\hline & Item 12 & $-0,75$ & Invalid \\
\hline & Item 13 & 0,135 & Valid \\
\hline & Item 14 & 0,513 & Valid \\
\hline & Item 15 & 0,340 & Valid \\
\hline & Item 16 & 0,442 & Valid \\
\hline & Item 17 & 0,030 & Invalid \\
\hline
\end{tabular}

Table 1. Validity Test 
2020, Jurnal Tabarru' : Islamic Banking and Finance 3 (1) : 11 - 19

\begin{tabular}{|c|c|c|c|}
\hline & Item 18 & 0,032 & Invalid \\
\hline & Item 19 & 0,496 & Valid \\
\hline & Item 20 & 0,732 & Valid \\
\hline & Item 21 & 0,535 & Valid \\
\hline & Item 22 & 0,370 & Valid \\
\hline & Item 23 & 0,645 & Valid \\
\hline & Item 24 & 0,592 & Valid \\
\hline & Item 25 & 0,591 & Valid \\
\hline & Item 26 & 0,852 & Valid \\
\hline & Item 27 & 0,185 & Invalid \\
\hline & Item 28 & 0,091 & Invalid \\
\hline & Item 29 & 0,782 & Valid \\
\hline & Item 30 & 0,784 & Valid \\
\hline & Item 30 & 0,594 & Invalid \\
\hline & Item 32 & 0,687 & Valid \\
\hline & Item 33 & 0,076 & Invalid \\
\hline & Item 34 & 0,139 & Invalid \\
\hline & Item 35 & 0,535 & Valid \\
\hline & Item 36 & 0,516 & Valid \\
\hline & Item 37 & 0,617 & Invalid \\
\hline & Item 38 & 0,617 & Valid \\
\hline & Item 39 & 0,672 & Valid \\
\hline & Item 40 & 0,758 & Valid \\
\hline & Item 41 & $-0,134$ & Invalid \\
\hline & Item 42 & $-0,01$ & Invalid \\
\hline & Item 43 & 0,818 & Valid \\
\hline $\bar{Y}$ & Item 44 & 0,884 & Valid \\
\hline & Item 45 & 0,811 & Valid \\
\hline & Item 46 & 0,759 & Valid \\
\hline & Item 47 & 0,740 & Valid \\
\hline & Item 48 & 0,848 & Valid \\
\hline & Item 49 & 0,830 & Valid \\
\hline & Item 50 & 0,830 & Valid \\
\hline & Item 51 & 0,751 & Valid \\
\hline & Item 52 & 0,256 & Invalid \\
\hline & Item 53 & 0,873 & Valid \\
\hline & Item 54 & 0,647 & Valid \\
\hline
\end{tabular}

\section{Reliability Test}

For reliability test, Cronbach Alpha technique was used, where an instrument can be deemed reliable if its reliability coefficient, or alpha, is 0.6 or more
(Sanusi,

Table 2. Reliability Test

\begin{tabular}{lll}
\hline Variables & Cronbach Alpha & $\begin{array}{l}\text { Result Description } \\
\text { (If Cronbach Alpha }>\mathbf{0 . 6} \\
\text { Reliable } \text { ”) }\end{array}$ \\
\hline $\mathrm{X} 1$ & 0,903 & Reliable \\
\hline $\mathrm{X} 2$ & 0,898 & Reliable \\
\hline $\mathrm{Y}$ & 0,942 & Reliable \\
\hline
\end{tabular}

Source : Processed Data (2018) 
Multiple Regression Analysis

From the calculation of multiple regression analysis through SPSS for
Windows version 23, the values for independent and dependent variables are showed in the table:

Table 3. Multiple Regression Analysis

\begin{tabular}{lllll}
\hline \multirow{2}{*}{ Model } & & \multicolumn{2}{c}{ Unstandardized Coefficients } & $\begin{array}{l}\text { Standardized } \\
\text { Coefficients }\end{array}$ \\
\cline { 3 - 5 } 1 & (Constant) & B & Std. Error & Beta \\
& Incentives (X1) & 5.996 & 11.705 & \\
& Leadership Style (X2) & .294 & .162 & .306 \\
& & .272 & .124 & .369 \\
\hline
\end{tabular}

Source : Processed Data (2018)

Based on the table above, following multiple regression equation can be formulated:

$Y=5,996+0,294 X^{1}+0,272 X^{2}$

Numbers in the equation above represent constant value (a) of 5.996. It means that if the incentive is assumed to be zero (0), then the work performance (Y) is 5.996. the value of regression coefficient of incentive variable (X1) is
0.294 which means that every increase in incentive factor by one unit will increase work performance factor (Y) by 0.294 with the assumption that $\mathrm{X} 2$ variable is constant. The regression coefficient value of Leadership Style variable (X2) is 0.272 , meaning that every increase in Leadership Style factor by one unit will increase Work Performance (Y) by 0.272 with the assumption that $\mathrm{X} 1$ is constant.

Table 4. T-Test (Partial Test)

\begin{tabular}{|c|c|c|c|c|c|c|}
\hline \multirow[b]{2}{*}{ Model } & & \multicolumn{2}{|c|}{ Unstandardized Coefficients } & \multirow{2}{*}{$\begin{array}{l}\text { Standardized } \\
\text { Coefficients } \\
\text { Beta }\end{array}$} & \multirow[b]{2}{*}{$\mathrm{t}$} & \multirow[b]{2}{*}{ Sig. } \\
\hline & & $\mathrm{B}$ & Std. Error & & & \\
\hline \multirow[t]{3}{*}{1} & (Constant) & 5.996 & 11.705 & & .512 & .613 \\
\hline & Incentive (X1) & .294 & .162 & .306 & 1.809 & .042 \\
\hline & $\begin{array}{l}\text { Leadership } \\
\text { (X2) }\end{array}$ & ${ }^{\text {Style }} .272$ & .124 & .369 & 2.185 & .038 \\
\hline
\end{tabular}

Source: Processed Data (2018)

- If $-\mathrm{t}$ table $\leq \mathrm{t}$ count $\leq+\mathrm{t}$ table, then Ho is accepted and Ha is rejected.

- If $-\mathrm{t}$ table $\geq \mathrm{t}$ count $\geq+\mathrm{t}$ table, then Ho is rejected and Ha is accepted.

From the data processing above, the value of $t$-count of Incentive variable (X1) is 1.809 and the value of t-table is 1.703 with significance level of 0.05 and a degree of freedom of $27(\mathrm{dk}=\mathrm{n}-\mathrm{k}-1$ $(30-2-1))$, Thus, it is clear that: $t$-count $>\mathrm{t}$-table or $1.809>1.703$. This indicates that $\mathrm{Ho}$ is rejected and $\mathrm{Ha}$ is accepted, in other words, there is a significant effect between incentives with agent work performance variable. The value of $\mathrm{t}$ count of Incentive variable (X2) is 2.185 and the value of t-table is 1.703 with significance level of 0.05 and degree of freedom of 27 (dk=n-k-1 (30-2-1)), thus, it is clear that: $t$-count $>\mathrm{t}$-table or $2.185>1.703$. It indicates that $\mathrm{Ho}$ is rejected and $\mathrm{Ha}$ is accepted, in other words, there is a significant effect between incentives with agent work performance variable. 
Simultaneous Test (F Test)

$F$ test is used to determine the effect of each independent variable on dependent variable. The results of the $\mathrm{F}$ test are as follows:

Table 5. Simoultanoes Test (F-Test)

\begin{tabular}{lllllll}
\hline Model & & Sum of Squares & Df & Mean Square & F & Sig. \\
\hline 1 & Regression & 184.604 & 2 & 92.302 & 5.726 & $.008^{\mathrm{b}}$ \\
& Residual & 435.263 & 27 & 16.121 & & \\
& Total & 619.867 & 29 & & & \\
\hline
\end{tabular}

Source : Processed Data (2018)

The table above shows that the f-count is 5.726, while the f-table at significance level $(\alpha)$ of 5 and with df 2 of 27 (n-k$\mathrm{l}=30-2-1)$ is 3.35 . Therefore, f-count $>\mathrm{f}-$ table is $5.726>3.35$ which means that Ho is rejected. It means that the independent variables (Incentives and Leadership Style) together have a significant effect on dependent variable (Work Performance).

\section{Correlation Coefficient}

To identify the relation between independent variables and dependent variable, correlation coefficient is used with SPSS for Windows version 23. The results is showed in the table below:

Tabel 6. Correlation Coeficient

\begin{tabular}{ccclc}
\hline Model & $\mathrm{R}$ & R Square & $\begin{array}{l}\text { Adjusted } \\
\text { Square }\end{array}$ & $\begin{array}{c}\text { RStd. Error of the } \\
\text { Estimate }\end{array}$ \\
\hline 1 & $.546^{\mathrm{a}}$ & .298 & .246 & 4.0151 \\
\hline \multicolumn{4}{c}{ Source : Processed Data (2018) }
\end{tabular}

$\mathrm{R}$ value shows multiple correlation between independent and dependent variables. In the table, the $\mathrm{R}$ value is 0.546 or $54.6 \%$. It means that the multiple correlation between $\mathrm{X}$ variables (Incentives and Leadership Style) and Y variable (Work Performance) is fairly strong.

\section{Coefficient of Determination}

With the adjust value of $\mathrm{R}$ Square of 0.246 , the contribution of the effect of independent variables (Incentives and Leadership Style) to Y variable (Work Performance) is $24.6 \%$, while the other $75.3 \%$ are influenced by other variables not included in this model.

\section{CONCLUSION}

1. The incentive has positive influence and significance toward agent work performance with t-test value of 0.42 or $<0.05$ (significant value) and regression coefficient of incentive $\left(\mathrm{X}_{1}\right)$ of 0.294 . It means that increasing in Incentive will increase agent work performance.

2. The leadership style also has positive influence and significance toward agent work performance with t-test value of 0.38 or $<0.05$ (significant value) and regression coefficient of leadership style $\left(\mathrm{X}_{2}\right)$ of 0.272 . It means that increasing in leadership style will increase agent work performance. 
3. Simultantly, the incentive and leadership style has positive influence and significance toward agent work performance with f-test value of 0.008 or $<0.05$ (significant value). It means the incentive and leadership style increasing simultantly will increase agent work performance.

4. Suggestion, PT Asuransi Takaful Keluarga RO Riau Agency Pekanbaru should always give incentive to their agent fairly and create best leader to increase their agent work performance.

5. Futher research, it need other research with other variable (except; Incentive and Leadership styel) to measure agent work performace.

\section{REFERENCES}

Akdon dan Riduwan. 2013. Rumus dan Data dalam Aplikasi Statistika. Alfabeta. Bandung.

Ali, Zainuddin. 2008. Hukum Asuransi Syariah. Sinar Grafika. Jakarta.

Davis, K dan Newstrom. 1995. Perilaku dalam Organisasi. Erlangga. Jakarta.

Handoko, T. Hani. 2013. Manajemen Edisi 2. Anggota IKAPI. Yogyakarta.

Hasan, Iqbal. 2010. Produk-Produk Materi Statistic I (Statistic Deskriptif). PT. Bumi Aksara. Jakarta.

Hasibuan, Malayu S.P. 2009. Manajemen Sumber Daya Manusia, Edisi Revisi. PT. Bumi Aksara. Jakarta.

Hasibuan, Malayu S.P. 2013. Manajemen Sumber Daya Manusia, Edisi Revisi. PT. Bumi Aksara. Jakarta.
Sanusi, Anwar. 2014. Metodologi Penelitian Bisnis. Salemba Empat. Jakarta.

Siagian, P Sondang. 1999. Manajemen Sumber Daya Manusia. Cetakan Ketujuh. Jakarta: Bumi Aksara, 1999.

Soemitra, Andri. 2009. Bank dan Lembaga Keuangan. Kencana. Jakarta.

Sutrisno, Edi. 2011. Manajemen Sumber Daya Manusia. Kencana. Jakarta.

Syakir Sula, Muhammad. 2004. Asuransi Syariah (Life And General): Konsep Dan Sistem Operasional. Gema Insani Press. Jakarta.

Thoha, Miftah. 2004. Perilaku Organisasi: Konsep Dasar dan Aplikasinya. RajaGrafindo Persada. Jakarta.

Tjiptono, Fandy. 2006. Manajemen Jasa, Edisi Pertama. Andi. Yogyakarta.

Winardi. 2008. Motivasi Dan Pemotivasi Dalam Manajemen. PT Rajagrafindo Persada. Jakarta. 